\title{
Gerakan Ekonomi Islam Kontemporer: Studi terhadap Perkembangan Mitra Koperasi Syariah 212 di Kalimantan Selatan
}

\section{Yulia Hafizah}

Fakultas Ekonomi dan Bisnis Islam, Universitas Islam Negeri Antasari, Indonesia. E-mail: yuliahafizah79@gmail.com

\section{Erissa Nilasari}

Fakultas Ekonomi dan Bisnis Islam, Universitas Islam Negeri Antasari, Indonesia. E-mail: erissanilasari@ymail.com

\section{ARTICLE INFO}

Kata Kunci:
Ekonomi Islam; Koperasi
Syariah 212
Cara Sitasi:
Hafizah, Yulia, Erissa
Nilasari. "Gerakan
Ekonomi Islam
Kontemporer: Studi
terhadap
Perkembangan Mitra
Koperasi Syariah 212
di Kalimantan
Selatan.” At-Taradhi:
Jurnal Studi Ekonomi
11, no. 1 (2020): 1-17.

\begin{abstract}
This research intends to read the latest phenomenon related to the contemporary Islamic economic movement in Indonesia, by taking the scope of the study of the development of the 212 Syariah Cooperative partners in South Kalimantan. The political movement that brought together a large number of Muslims to demonstrate on 2 December 2016 has had a powerful influence, not only on the political sphere but also on the economic dimension, which is seen as the root cause of the backwardness of Muslims. This research is a field study that took place in South Kalimantan: Banjarmasin, Banjarbaru and Kota Baru. Data mining is carried out using in-depth interviews with informants who are considered to know the issues to be answered. Data analysis was performed using discourse analysis with interpretation techniques. The findings of this study are that: First, the background of Muslims in South Kalimantan joined and established the Syariah Cooperative partner 212 due to the influence of spirit 212 that can offer something different but following the character of the people in the three cities that are more open and tend to be religious and cautious heart to the problem muamalah. Secondly, the development of the Syariah Cooperative 212 partners showed positive developments. Third, the inhibiting factors are members' understanding of the character of cooperative institutions which are still lacking, there are more pressing needs so that they attract savings funds, and the last regarding prospects for Sharia Cooperative 212 partners in developing the people's economy is the presence of these cooperatives provides an alternative investment place and sharia-compliant shopping for the people in Banua and institutionally have the opportunity to become even greater if they do not limit themselves only to certain ideological groups, but to make room for others by sticking to the principles for the economic empowerment of the people.
\end{abstract}

Penelitian ini bermaksud membaca fenomena mutakhir terkait gerakan ekonomi Islam kontemporer di Indonesia, dengan mengambil lingkup studi perkembangan mitra Koperasi Syariah 212 di Kalimantan Selatan. Gerakan politik yang menghimpun sejumlah besar umat Islam melakukan demonstrasi pada 2 Desember 2016 telah memberikan pengaruh kuat, bukan saja pada wilayah politik, tetapi juga pada dimensi ekonomi, yang dipandang sebagai akar persoalan dari ketertinggalan umat Islam. Penelitian ini merupakan kajian lapangan yang mengambil wilayah di Kalimantan Selatan, 
yakni Banjarmasin, Banjarbaru dan Kota Baru. Penggalian data dilakukan dengan menggunakan indepth interview kepada para informan yang dianggap mengetahui terhadap persoalan yang ingin dijawab. Analisis data dilakukan dengan menggunakan analisis wacana dengan teknik interpretasi. Temuan dari penelitian ini adalah: Pertama, latarbelakang umat Islam di Kalimantan Selatan bergabung dan mendirikan mitra Koperasi Syariah 212 karena pengaruh spirit 212 yang mampu menawarkan sesuatu yang berbeda namun bersesuaian dengan karakter dari masyarakat di tiga kota tersebut yang lebih terbuka dan cenderung religius serta berhati-hati pada persoalan muamalah. Kedua, perkembangan mitra Koperasi Syariah 212 menunjukkan perkembangan yang positif. Ketiga, faktor-faktor yang masih menjadi kendala dalam perkembangan mitra Koperasi Syariah 212 adalah pemahaman anggota terhadap karakter lembaga koperasi yang masih kurang, adanya kebutuhan yang lebih mendesak sehingga mereka menarik dana simpanan, dan yang terakhir mengenai prospek mitra Koperasi Syariah 212 dalam pengembangan ekonomi umat adalah hadirnya koperasi ini memberikan alternatif tempat investasi dan belanja yang sesuai syariah bagi umat di Banua dan secara kelembagaan memiliki peluang untuk menjadi lebih besar lagi apabila tidak membatasi dirinya hanya pada kalangan dengan ideologi tertentu saja, tetapi memberikan ruang bagi yang lainnya dengan tetap berpegang pada prinsip untuk pemberdayaan ekonomi umat.

\section{Pendahuluan}

Gerakan sosial berbasis religius dalam Islam bisa ditelusuri dari perkembangan gerakan pemurnian Islam. ${ }^{1}$ Di Nusantara, gerakan ini bisa dilihat pada kasus kaum Paderi oleh Imam Bonjol, ${ }^{2}$ adat Banjar oleh Syekh Muhammad Arsyad, ${ }^{3}$ Muhammadiyah, Al-IrsyadPersis dan Salafi (Wahhabi). ${ }^{4}$ Gerakan ini tidak hanya berbicara pada persoalan akidah dan ibadah semata, tetapi merambah dalam berbagai aspek seperti sosial, politik dan ekonomi.

Dalam bidang ekonomi, gerakan ini bisa dilihat dari pendirian perbankan syariah. Perjalanan panjangnya dimulai sejak tahun 1940 di Malaysia dan Pakistan, ${ }^{5}$ yang kemudian berpengaruh ke tanah air. Keinginan ini tidak serta merta dapat terwujud, karena masih dicurigai sebagai bagian dari upaya mendirikan Negara Islam. Seiring bergulirnya waktu dan

\footnotetext{
${ }^{1}$ Mutohharun Jinan, “Dilema Gerakan Pemurnian Islam,” Ishraqi IV, no. 1 (June 2008).

2 Syafwan Razi, "Dari Islam Radikal Ke Islam Pluralis Genealogi Gerakan Paderi Dan Pengaruhnya Terhadap Islam Pluralis Di Perbatasan Minangkabau," Masyarakat Indonesia 41, no. 1 (2016): 15-27; Haedar Nashir, "Purifikasi Islam Dalam Gerakan Padri Di Minangkabau," UNISIA 31, no. 69 (2008). Lihat juga Rahmad Suriamijaya, "Pemikiran Dakwah Kaum Padri Di Sumatera Barat (Gerakan Dakwah Dalam Purifikasi Islam Di Masyarakat Minangkabau)" (PhD Thesis, Universitas Muhammadiyah Surakarta, 2011).

3 Anita Arianti, "Gerakan Pemurnian Islam Syekh Muhammad Arsyad Al-Banjari Di Kalimantan Selatan," AL-Fiker 14, no. 3 (2017): 377-390.; Rahmadi, "Dinamika Intelektual Islam Di Kalimantan Selatan: Studi Genealogi, Referensi, Dan Produk Pemikiran,” Jurnal Ilmu Ushuluddin 11, no. 1 (2016): 1-19.

${ }^{4}$ Din Wahid, "Nurturing Salafi Manhaj; A Study of Salafi Pesantrens in Contemporary Indonesia," Wacana 15, no. 2 (2014): 367-376.; Ahmad Buyan Wahid, "DAKWAH SALAFI: DARI TEOLOGI PURITAN SAMPAI ANTI POLITIK," Media Syari'ah 13, no. 2 (2017): 147-162.
}

${ }^{5}$ Muhammad Syafi'i Antonio Bank Syariah: dari Teori ke Praktek (Jakarta : Gema Insani Press, 2001), 18-21. 
perubahan arah politik pemerintah Orde Baru yang lebih akomodatif kepada umat Islam, maka akhirnya berdirilah bank syariah tahun 1992. Dewasa ini keberadaan perbankan syariah semakin diterima dan dipandang sebagai bentuk gerakan pemurnian Islam yang paling berhasil. ${ }^{6}$

Gerakan ekonomi Islam juga bisa dilihat dari adanya upaya institusionalisasi pengelolaan zakat. Bermula dari inisisasi tokoh MUI, Buya Hamka yang akhirnya berhasil membentuk BAZ pada 26 Oktober 1968. Selanjutnya gerakan filantropi Islam ini terus berkembang diberbagai daerah seperti Aceh, Kalimantan, Jawa Tengah, Jawa Timur dan Sumatera Barat. Geliat aktivitas dari lembaga tersebut makin terasa setelah tahun 1990-an dengan dikeluarkannya UU No. 38 tahun 1999 yang selanjutnya diubah menjadi UU No. 23 tahun 2011 tentang Pengelolaan Zakat. Sampai saat ini akhirnya kita dapat dengan mudah menemukan lembaga pengelolaan zakat di Indonesia baik itu yang dikelola oleh pemerintah (BAZ) dan non-pemerintah (LAZ). ${ }^{7}$

Perkembangan zaman melahirkan tantangan dan persoalan tersendiri bagi umat Islam. Demo 212 di Lapangan Monas Jakarta di penghujung 2016 menjadi inspirasi untuk kebangkitan ekonomi umat. Para eksponen 212 melihat potensi besar umat Islam dalam 'membela' agamanya, kemudian menariknya ke persoalan ekonomi, yang dipandang sebagai titik lemah umat Islam. Konkretnya, kemudian didirikanlah Koperasi 212 pada tanggal 6 Januari 2017, dengan semboyan amanah, berjamaah dan izzah. Selanjutnya, dibangunlah 212 Mart, KITAMart, dan Sodaqo Mart.' Tujuannya sama, yakni ingin mewujudkan kemandirian dalam berekonomi, bisa lepas dari ketergantungan dengan pihak asing yang notabene beraliran ekonomi kapitalis.

Strategi yang direncanakan adalah menguasai jaringan waralaba dan minimarket secara nasional, akuisisi pabrik-pabrik dan manufaktur yang menguasai hajat hidup orang banyak, bermitra dengan sebanyak mungkin warung-warung tradisional yang ada di sekitarnya. ${ }^{10}$ Bagi pegiatnya, gerakan ini sebagai bagian dari jihad ekonomi. ${ }^{11}$

Semangat ini ternyata meluas ke pelosok Indonesia, tidak terkecuali Bumi Banjar yang penduduknya mayoritas Muslim dan dikenal agamis. Menurut M. Ismail, setelah launching Koperasi Syariah 212 di Sentul City, tidak kurang dari 250 orang berkomitmen untuk

\footnotetext{
6 Ada beberapa faktor yang juga turut memengaruhi pertumbuhan dari perbankan syariah saat ini yakni konversi beberapa Bank Pembangunan Daerah ke perbankan syariah, implementasi beberapa kebijakan daerah dan meningkatnya tren industri halal. Lihat Rahajeng Kusumo Hastuti, "5 Tahun Rerata Pertumbuhan Industri Perbankan Syariah 15\%," syariah, accessed June 20, 2020, https://www.cnbcindonesia.com/syariah/20190608180708-29-77170/5-tahun-rerata-pertumbuhan-industriperbankan-syariah-15.
}

${ }^{7}$ Lihat Asep Saepuddin Jahar, “Transformasi Gerakan Ekonomi Islam Kontemporer,” MIQOT: Jurnal IlmuIlmu Keislaman 39, no. 2 (2015): 331-33.

8 “Koperasi Syariah 212," Koperasi Syariah 212 (blog), accessed February 27, 2018, http://koperasisyariah212.co.id/koperasi-syariah-212/.

9 "Dampak Pergerakan 212 Terhadap Perkembangan Ekonomi Umat Muslim," Koperasi Syariab 212 (blog), July 3, 2017, https://koperasisyariah212.co.id/dampak-pergerakan-212-terhadap-perkembangan-ekonomiumat-muslim/.

10 Yayu Agustini Rahayu, “Tingkatkan Ekonomi Rakyat, 212 Mart Gandeng UMKM Dan Warung Kecil," merdeka.com, accessed April 24, 2018, https://www.merdeka.com/uang/tingkatkan-ekonomi-rakyat-212mart-gandeng-umkm-dan-warung-kecil.html.

11 "Dampak Pergerakan 212 Terhadap Perkembangan Ekonomi Umat Muslim." 
mendirikan 212 Mart di Banjarmasin. Mereka menginginkan perekonomian umat bangkit melalui kebersamaan dan silaturrahmi. ${ }^{12}$ Akhirnya komitmen ini terwujud pada 3 Februari 2018, dibukalah gerai usaha dari mitra Koperasi Syariah 212, yang berbentuk 212 Mart oleh Walikota Banjarmasin, diikuti dengan Banjarbaru dan Kotabaru. ${ }^{13}$ Pemerintah Kota Banjarmasin, sangat mendukung terhadap kehadiran usaha ini dengan pemberian izin untuk mendirikan 10 gerai usaha minimarket lagi di Banjarmasin. ${ }^{14}$

Perilaku masyarakat Banjar pasca Aksi 212 tersebut, yang secara "bersama-sama" ingin membangun perekonomian, mengalami perubahan jika dibandingkan dengan hasil penelitian yang dilakukan LIPI dan IAIN Antasari tahun 1983. Hasil penelitian ini menyebutkan bahwa perilaku masyarakat Banjar dalam berekonomi yang direpresentasikan dengan kegiatan berdagang, tergolong pada sikap individualistik-kompetitif. Sikap ini tumbuh dan berkembang menjadi stereotype orang Banjar, karena mereka sebagian besar hidup di pesisir sungai. ${ }^{15}$

Adanya perubahan perilaku ekonomi tersebut yang terjadi dalam kurun waktu relatif singkat, menimbulkan pertanyaan sebagai berikut: apa yang melatarbelakangi umat Islam bergabung dalam komunitas kemudian mendirikan mitra Koperasi 212 di Kalimantan Selatan? Bagaimana perkembangan mitra Koperasi 212 di Kalimantan Selatan? Faktorfaktor apa saja yang menghambat perkembangan mitra Koperasi 212 di Kalimantan Selatan? Terakhir, bagaimana prospek mitra Koperasi 212 dalam pengembangan ekonomi umat?

\section{Tinjauan Pustaka}

\section{Munculnya Gerakan Sosial}

Dalam kajian sosiologi dikatakan bahwa perubahan sosial tidak terjadi secara tiba-tiba. Terjadinya perubahan sosial di Indonesia seperti pergantian rezim yang berkuasa, seringkali memerlukan upaya keras sekelompok orang yang menginginkan perubahan sosial di Indonesia. Sekelompok orang tersebut menyampaikan aspirasi, kritikan atau bahkan protes mereka dalam jargon demokrasi. Sekerumunan orang yang membentuk sebuah kelompok tersebut dalam studi mengenai perubahan sosial dinamakan dengan gerakan sosial (social movement).

\footnotetext{
12 Rahayu, “Tingkatkan Ekonomi Rakyat, 212 Mart Gandeng UMKM Dan Warung Kecil.”

13“"Koperasi Syariah 212."

14 “Walikota Resmikan 212Mart Banjarmasin," Koperasi Syariah 212 (blog), February 5, 2018, http://koperasisyariah212.co.id/walikota-resmikan-212mart-banjarmasin/. Sementara itu untuk pendirian usaha minimarket yang dimiliki oleh PT Alfaria (Alfamart) dan PT Indomarco Prismatama (Indomaret), pemkot Banjarmasin mengeluarkan instruksi untuk melarang penambahan gerainya sejak Maret 2016. Lihat Sukarli "Stop Izin Alfamart dan Indomaret", https://kalsel .antaranews.com/berita/, diakses pada 17 September 2018.

15 Mochtar Buchori dan Wiladi Budiharga, “Tipe-Tipe Orientasi Sosial Budaya di Sembilan Daerah Penelitian di Indonesia “ Makalah dalam Seminar Orientasi Sosial Budaya III di Banjarmasin, diselenggarakan atas kerjasama LIPI dengan IAIN Antasari tanggal 28 Nopember - 1 Desember 1983, 43-44. Lihat juga Irfan Noor, "Demokrasi dan Budaya Banjar; Modal Kultur dan Penguatan Masyarakat Sipil", bttps://wmw.scribd.com/document/7851159/Demokrasi-Dan-Budaya-Banjar, diakses tanggal 23 April 2018, 3-4. Lihat juga Ahmadi Hasan, "Prospek Pengembangan Ekonomi Syariah di Masyarakat Banjar Kalimantan Selatan," AHKAM:Jurnal Ilmu Syariah 14, no. 2 (March 19, 2015).
} 
Menurut Sunarto (2004), gerakan sosial pada hakikatnya lahir dari perilaku kolektif, yaitu perilaku yang dilakukan bersama-sama oleh sejumlah orang, tidak rutin dan biasanya perilaku mereka ini merupakan respon atau tanggapan terhadap suatu persoalan. Gerakan sosial bersifat terorganisir, mem iliki tujuan dan kepentingan bersama untuk menuntut perubahan, dan seringkali ditujukan terhadap pemerintah atau penguasa. ${ }^{16}$

Tilly (1978) menyatakan bahwa teori proses politik erat kaitannya dengan teori mobilisasi sumber daya. Pendekatan dalam proses politik ini menekankan pada peluang-peluang bagi gerakan yang diciptakan oleh proses politik dan sosial yang lebih besar. ${ }^{17}$ Hasan (2006) dalam reviewnya terhadap buku Islamic Activism, A Social Movement Theory Approach menyebutkan bahwa terdapat tiga variabel kunci atas keberhasilan dari gerakan sosial, yakni (1) struktur kesempatan politik (political opportunity structure), (2) struktur mobilisasi (mobilizing structures) dan (3) pembingkaian aksi (framing). ${ }^{18}$ Selanjutnya, Hasan menjelaskan bahwasanya variabel struktur kesempatan politik muncul seringkali dipicu oleh perubahan-perubahan signifikan yang terjadi dalam struktur politik, bahkan meredupnya gerakan sosial pun sangat berhubungan dengan pergeseran-pergeseran yang terjadi dalam struktur politik. Adanya kesempatan memasuki struktur politik dapat mempercepat proses atau memperlambat sebuah gerakan sosial. Akan tetapi struktur kesempatan politik saja dirasa tidak cukup dalam mendorong terjadinya aksi kolektif. Hal itu juga harus ditopang oleh struktur mobilisasi yang berakar dalam jaringan-jaringan sosial yang sudah terbangun sebelumnya. Melalui jaringan itu, massa dan simpatisan (baca: follower) direkrut dan dimobilisasi. Untuk memobilisasi massa itulah aktor-aktor gerakan sosial perlu membingkainya dengan sloganslogan dan bahasa yang mudah dipahami, sekaligus dapat menggerakkan sentimen massa. Disinilah peranan penting dari framing sebagai seni dalam mengkomunikasikan pesan untuk menggerakkan audien, memompa dukungan. Ideologi, sebagai sistem kepercayaan, ide, nilai dan makna biasanya cukup efektif untuk mendukung framing ini. ${ }^{19}$

Seiring perkembangan zaman, sarana framing mengalami transformasi ke cyberactivism. Jati (2016) menyebutkan bahwa cyberactivism merupakan istilah akademik yang senantiasa digunakan dalam menganalisa pola gerakan yang berkembang pasca reformasi di Indonesia. Istilah ini merujuk pada pola gerakan berdasarkan pada preferansi diskusi internet dan media sosial. Internet membuat gerakan sosial lebih mudah dilakukan. Untuk melakukan gerakan sosial, tidak harus berkumpul puluhan atau ratusan ribu orang di lapangan. Mobilisasi bisa dilakukan secara online, dan dukungan seseorang terhadap sebuah isu bisa dilakukan dengan melakukan klik dukungan. Dan pada teori new social movement, diskusi publik dapat berujung pada aksi-aksi penggalangan massa berdasarkan istilah viral dalam dunia maya (netizen). ${ }^{20}$ Tetapi, internet dan aneka aplikasi hanyalah medium. Keberhasilan gerakan sosial tergantung kepada apakah pemimpin gerakan mampu mengemas isu, masalah atau kebijakan sehingga isu tersebut menjadi isu bersama dan membuat publik rela terlibat dalam sebuah gerakan.

\footnotetext{
16 Nanang Martono, Sosiologi Perubahan Sosial: Perspektif Kalasik, Modern, Posmodern, Dan Poskolonial, 3rd ed. (Jakarta: Rajawali Press, 2014), 391-92.

17 Nanang Martono, 397.

18 Noorhaidi Hasan, "Book Review: Islam Politik, Teori Gerakan Sosial, Dan Pencarian Model Pengkajian Islam Baru Lintas-Disiplin,” Al-Jami'ah: Journal of Islamic Studies 44, no. 1 (2006): 245.

${ }^{19}$ Hasan, 245.

20 Wasisto Raharjo Jati, “Aktivisme Kelas Menengah Berbasis Media Sosial: Munculnya Relawan Dalam Pemilu 2014," Jurnal Ilmu Sosial Dan Ilmu Politik 20, no. 2 (2016): 149-50.
} 


\section{Gerakan Sosial Ekonomi Kelas Menengah}

Kemampuan dalam memobilisasi massa dalam cyberactivism dalam tulisan Jati ditelisik sebagai bagian dari aktivitas yang dilakukan oleh masyarakat kelas menengah. Keterlibatan kelompok masyarakat ini dalam melakukan memobilisasi diskusi dan opini dalam media internet sangat terasa dalam Pemilu 2014. ${ }^{21}$ Adelman dan Morris (1967) serta Landes (1998), sejarawan ekonomi yang menyatakan bahwa keberadaan kelas menengah sangat berpengaruh dalam memberikan kekuatan pendorong (driving force) terhadap proses pembangunan ekonomi yang lebih cepat di Inggris serta daratan Eropa pada abad ke-19. ${ }^{22}$

Weber dalam bukunya yang berjudul Economy and Society yang melihat adanya keterkaitan antara posisi kelas dengan pembangunan pasar. Konsepsi kelas dalam pemahaman Weber ini sangat heterogen karena banyaknya diferensiasi kepentingan dalam kelas, sehingga pengertian pasti terhadap kelas menengah belum dapat dirumuskan. Yang jelas kelas menengah dapat disebut dengan petit buorguoise untuk melihat peran sentralnya dalam perekonomian. Namun penyebutan istilah tersebut pun tidak berlaku universal mengingat kelas menengah inipun juga memegang peranan sebagai leisure class dan juga intellectual class dalam ranah sosial. Sehingga adanya segmen dari kelas sosial menengah ini sudah menunjukkan spesialisasi dari perannya diberbagai bidang. ${ }^{23}$

Adanya variasi tools yang dimiliki kelas menengah (konsumsi, produksi dan ide) menjadikan pembangunan ekonomi bergerak demikian cepatnya. Rasionalitas dalam berekonomi pada akhirnya menghasilkan laba maksimal yang disertai dengan peningkatan jumlah properti. Selanjutnya jumlah kepemilikan atas asset ini pun menimbulkan adanya prestise dalam sebuah kelas. Have property dan non property, demikian istilah yang digunakan Weber.

Rasionalitas dalam berekonomi tersebut tentu tidak terlepas dari paham Calvin (Calvinisme) dan Metodisme yang percaya pada konsep predistinasi. Pembangunan ekonomi tidak dapat dilepaskan dari faktor mental dan etika yang diperoleh dari pemahaman atas ajaran agama yakni asketisme dan kerja keras. Keduanya diyakini sebagai faktor penentu untuk meraih kebahagian di dunia dan akhirat. Keduanya pula memiliki andil dalam membentuk akumulasi kapital sehingga terbentuklah kelas sosial. Agama dipahami sebagai sebuah unsur spritualisme yang memiliki korelasi kuat dalam membentuk sebuah etos ekonomi. Hal inilah yang kemudian secara konsisten sangat mendukung terhadap perkembangan ekonomi kapitalisme ${ }^{24}$ dan mampu menggerakkan ekonomi ini menjadi ideologi ekonomi di beberapa negara Eropa masa itu.

ALVARA Reseach Centre di tahun 2017, meluncurkan hasil penelitian tentang kelas menengah muslim sebagai tema utamanya. Dalam hasil penelitian tersebut dijelaskan bahwa kelas menengah muslim di Indonesia memiliki kecenderungan pandangan agama yang moderat. Pandangan ini diperoleh berdasarkan karakteristik yang dimiliki oleh masyarakat kota (urban population) yang lebih terbuka. Masyarakat kota juga lebih menyukai sesuatu yang

\footnotetext{
${ }^{21}$ Jati, “Aktivisme Kelas Menengah Berbasis Media Sosial.”

22 Muhammad Afdi Nizar, "Kelas Menengah (Middle Class) Dan Implikasinya," ResearchGate, 1, accessed August 2019, https://www.researchgate.net/publication/279406954_Kelas_Menengah_Middle_Class_dan_Implikasinya.

23 Wasisto Raharjo Jati, "Kelas Menengah Sebagai Basis Pembangunan: Telaah Perspektif Webberian,” n.d., 871.

24 Damsar and Indrayani, Pengantar Sosiologi Ekonomi (Jakarta: Prenada Media Group, 2015), 71, http:/ /opac.library.um.ac.id/oaipmh/../index.php?s_data=bp_buku\&s_field=0\&mod=b\&cat=3\&id=56646.
} 
bersifat simbolik, karenanya banyak simbol-simbol agama yang ditunjukkan oleh masyarakat kota dalam rangka memperlihatkan kesalehan pada khalayak. Simbol-simbol tersebut berkorelasi dengan budaya konsumerisme tersebut. Munculnya trend produk halal, acara-acara Islami yang tayang hampir setiap hari, juga butik-butik hijab dan pakaian muslim dapat dengan mudah ditemukan. ${ }^{25}$

Dalam perkembangan saat ini kiranya patut diperhatikan tulisannya Kees De Groot (2009) yang menyampaikan istilah liquid religion life di era modern. Groot menggunakan istilah tersebut untuk menunjukkan kondisi keberagamaan masyarakat yang begitu cair. Perubahan yang begitu cepat sehingga seringkali hal itu tidak disadari oleh individu. Sehingga menurutnya tipe keberagamaan manusia modern saat ini dapat dikelompokkan menjadi 3 tipe yakni: (1) fenomena cair dibidang keagamaan. Ia mencontohkan dengan pertemuan individu dalam acara-acara keagamaan, komunitas kecil, jaringan keagamaan yang bersifat global dan komunitas virtual. (2) keberagamaan dalam baluran kultur sekuler. Ia mencontohkan dengan munculnya acara-acara televisi, film, website, radio yang bernuansa religi. (3) kegiatan pertemuan dan perkumpulan diluar lingkungan keagamaan. Misalnya keterlibatan individu dalam sebuah proses politik. ${ }^{26}$

Dalam sektor ekonomi, gerakan ekonomi Islam di Indonesia dari awal kemerdekaan hingga saat ini senantiasa mengalami perubahan. Awal kemerdekaan misi gerakannya lebih menonjolkan pada semangat nasionalisme dan keagamaan yang diwakili oleh ormas-ormas Islam, seperti Sarekat Islam. Pada masa kemerdekaan, reformasi hingga saat ini, menurut Asep Saepudin Jahar, gerakan ekonomi lebih menekankan pada semangat entrepreneurship untuk pengembangan masyarakat. Semangat Islam juga menguat terutama ketika berhadapan dengan sistem kapitalis yang dianggap tidak memberikan penyelesaian terhadap persoalan ekonomi dan sosial di masyarakat. Karenanya semangat pendirian bank syariah dan lembaga filantropi Islam hadir sebagai bentuk kesadaran untuk mengembangkan masyarakat Muslim. Perkembangan selanjutnya semangat keislaman ini melebur pada konteks demokratisasi yang menekankan pada aspek akuntabilitas dan transparansi, tidak lagi semata-mata tertuju pada agama. ${ }^{27}$

\section{Metode Penelitian}

Penelitian ini adalah penelitian lapangan (field research) yang sifatnya kualitatif, dengan menggunakan pendekatan sosio-ekonomi. Penelitian ini secara umum mengambil lokasi di wilayah Provinsi Kalimantan Selatan, khususnya tempat-tempat dimana mitra Koperasi Syariah 212 itu berada, yakni di seputaran Kota Banjarmasin, Kota Banjarbaru dan Kabupaten Kotabaru. Pengumpulan data dilakukan melalui observasi dan wawancara kepada para pihak yang dianggapmengetahui terhadap persoalan dalam penelitian ini.

Analisis data dilakukan dengan menggunakan analisis wacana dengan teknik interpretasi. Untuk mendapatkan kesimpulan, dipergunakan dengan metode reflektif (deduktif-induktif)

\footnotetext{
${ }^{25}$ Hasanuddin Ali Ali Hasanuddin, "Pasar Kelas Menengah Muslim yang Menggiurkan - Kolumnis Tirto.ID," tirto.id, accessed August 8, 2019, https://tirto.id/pasar-kelas-menengah-muslim-yang-menggiurkan-cmw6.

26 Kees de Groot, "Three Types of Liquid Religion," Implicit Religion 11, no. 3 (February 26, 2009): 277, https://doi.org/10.1558/imre.v11i3.277.

27 Asep Saepuddin Jahar, “Transformasi Gerakan Ekonomi Islam Kontemporer," MIQOT: Jurnal Ilmu-ilmu Keislaman 39, no. 2 (December 6, 2015): 338, https://doi.org/10.30821/miqot.v39i2.28.
} 
dan tata pikir devergen (kreatif-inovatif). Kerangka pikir berupa teori-teori seputar gerakan sosial berbasis relegiusitas.

\section{Hasil dan Analisis Penelitian}

\section{Latar belakang Berdirinya Komunitas Koperasi Syariah 212 di Kalimantan Selatan}

Sebagaimana paparan sebelumnya oleh Hasan tentang tiga variabel kunci atas keberhasilan suatu gerakan sosial, yakni adanya struktur kesempatan politik (political opportunity structure), yang kemudian diikuti oleh struktur mobilisasi (mobilizing structures) serta dikuatkan oleh suatu pembingkaian aksi (framing). ${ }^{28}$ Kemampuan framing yang dikombinasikan dengan sebuah ideologi sebagai sistem kepercayaan, ide, nilai dan makna biasanya cukup efektif dalam mengkomunikasikan pesan untuk menggerakkan audien, memompa dukungan. Framing dapat menentukan seseorang merasa menjadi bagian dari isu dan masalah yang diperjuangkan, dan bersedia secara bersama-sama melakukan tindakan kolektif ini.

Seiring perkembangan zaman, sarana framing mengalami transformasi ke cyberactivism. Cyberactivism merupakan istilah akademik yang dipergunakan untuk menganalisis pola gerakan yang berkembang pasca reformasi di Indonesia. Istilah ini merujuk pada pola gerakan berdasarkan pada preferensi diskusi internet dan media sosial. Internet membuat gerakan sosial lebih mudah dilakukan. Untuk melakukan gerakan sosial, tidak harus berkumpul puluhan atau ratusan ribu orang di lapangan. Mobilisasi bisa dilakukan secara online, dan dukungan seseorang terhadap sebuah isu bisa dilakukan dengan melakukan klik dukungan. Pada teori new social movement, diskusi publik dapat berujung pada aksi-aksi penggalangan massa berdasarkan istilah viral dalam dunia maya (netizen). ${ }^{29}$

Pola framing dan cyberactivism ini memiliki relevansi kuat dikaitkan dengan fenomena Aksi Damai 212 sebagai sebuah gerakan sosial umat Islam kontemporer yang memiliki dampak kuat dalam memengaruhikeputusan pemerintah terhadap Gubernur DKI saat itu, Basuki Tjahaja Purnama atau Ahok. Memang pada saat peristiwa tersebut, banyak alumni peserta aksi yang merasakan anugerah atas peristiwa tersebut. Kumpulan massa yang demikian banyaknya melakukan aksi merasa bersyukur karena pasca aksi damai tersebut ternyata mampu menumbuhkan energi kebangkitan umat yang luar biasa besarnya. Aksi damai yang dihadiri jutaan umat Islam, masyarakat Indonesia dari berbagai daerah dan pelosok, telah menjadi tonggak sejarah baru bagi gerakan umat di Indonesia. Fenomena 212 merupakan wujud semangat persatuan, keadilan dan ukhuwah Islamiyah serta rasa cinta terhadap bangsa ini.

Secara politik gerakan 212 memiliki kontribusi besar dalam memenangkan Anies-Sandi dalam pentas perpolitikan di ibukota. Dalam lingkup yang lebih luas gerakan ini juga sangat berperan dalam pertarungan pemilihan bupati dan gubernur di wilayah Indonesia lainnya. Pemilihan presiden di tahun 2019 juga melibatkan gerakan ini, yang umumnya berafiliasi kepada calon presiden Prabowo-Sandi yang dikalahkan dalam kontestasi tersebut, dan dianggap kekalahan tersebut dianggap karena pelaksanaan pemilu yang tidak fair, demikian kesan kuat dalam diskusi di kalangan pendukung gerakan 212.

\footnotetext{
${ }^{28}$ Hasan, "Book Review,” 245.

29 Wasisto Raharjo Jati, “Aktivisme Kelas Menengah Berbasis Media Sosial: Munculnya Relawan Dalam Pemilu 2014," Jurnal Ilmu Sosial Dan Ilmu Politik 20, no. 2 (2016): 149-50.
} 
Imbas dari aksi ini ternyata cukup besar dalam membentuk kesadaran lain bagi pegiat ekonomi Islam. Hal ini tercermin dalam banyaknya inisiatif dari beberapa pemikir muslim untuk mengelola potensi umat tersebut dengan mengalihkan energinya ke sektor ekonomi. Aksi damai tersebut juga mampu menyadarkan umat betapa mereka merupakan kelompok mayoritas yang memiliki daya tawar tinggi terhadap kebijakan pemerintah, yang selama ini dalam bidang ekonomi nampak lebih condong berpihak kepada kapitalis. Kehadiran mega bisnis retail modern yang hampir menguasai seluruh pasar di Indonesia seperti Alfamart dan Indomaret telah menyebabkan banyak pasar dan warung tradisional sepi bahkan sampai tutup menjadi salah satu sumber kekecewaan mereka. Adanya ajaran dari ekonomi Islam yang mengajarkan prinsip keadilan distributif atas kekayaan-jangan sampai kekayaan itu hanya bergulir disegelintir kelompok saja-dan adanya larangan monopoli, menjadi saluran efektif untuk mendirikan lembaga usaha yang sesuai dengan prinsip tersebut.

Berbagai inisiatif untuk mendirikan usaha, minimarket, waralaba serta serba-serbi usaha yang berlabel 212 terjadi secara cepat dan massif. 212 ternyata menjadi trade mark yang sangat menarik untuk diperebutkan. Angka 212, angka Wiro Sableng, ternyata mampu menimbulkan memori kuat akan kesuksesan dari aksi yang dilakukan oleh jutaan umat muslim yang datang dari seluruh penjuru. Ditambah lagi dengan framing dari peristiwa tersebut yang disisipi dengan ideologi keagamaan ternyata mampu untuk menggerakkan banyak orang untuk sadar terhadap agama yang dianutnya. Upaya implementasi ajaran agama yang dilakukan dengan sungguh-sungguh (jihad) dalam memberantas ketidakadilan dalam sektor ekonomi juga dipercayai sebagai sarana untuk meraih kebahagiaan di akhirat kelak. Sebagaimana Abd. A'la menuliskan jihad saat ini janganlah diartikan semata hanya dari aspek warfare, tapi harus dimaknai lebih besar lahi yaitu mewujudkan walfare. Jihad untuk mewujudkan kesejahteraan ekonomi, mengurangi angka kemiskinan, terutama di kalangan umat Islam.

Semangat tersebut begitu cepat menjalar ke daerah-daerah, menyeberang pulau, terutama di tiga wilayah Kalimantan Selatan membentuk sebuah gerakan ekonomi Islam baru. Melihat pada letak geografis, penduduk yang bermukim di sana dan tingkat ekonomi yang dimiliki, maka dapat digolongkan kepada masyarakat kelompok menengah. Sesuai dengan teori peran kelas menengah dalam perekonomian. Mereka berada pada posisi menengah dalam upaya memperjuangkan kepentingan bersama, baik sebagai class in itself (menyadari adanya perbedaan dirinya dengan kelompok masyarakat sehingga cenderung bersikap permisif dan kompromistis dengan kekuasaan) atan sebagai class for itself (menyadari adanya hubungan antara negara dan masyarakat dalam kerangka aktif, reaksioner dan kritis terhadap kekuasaan). Kemudian perdebatan dalam elemen keanggotaan kelas yang ditentukan oleh redistribusi materi, pertumbuhan kapital dan penguasaan asset. ${ }^{30}$

Tidak jauh berbeda dengan apa yang disampaikan Weber dalam bukunya yang berjudul Economy and Society yang melihat adanya keterkaitan antara posisi kelas dengan pembangunan pasar. Selanjutnya posisi kelas menengah (petit buorguoise) dalam perekonomian terletak pada peran konsumsi serta produksi yang dijalankan. Adanya dua peran ini kemudian menempatkan posisi kelas menengah itu dapat dikelompokkan sebagai kelas konsumen (new consumerism class), juga kelas pengusaha kecil (new petit bourgouise).

ALVARA Reseach Centre yang meneliti tentang kelas menengah muslim sebagai tema utamanya. Dalam hasil penelitian tersebut dijelaskan bahwa kelas menengah muslim di Indonesia memiliki kecenderungan pandangan agama yang moderat. Pandangan ini

\footnotetext{
${ }^{30}$ Jati, “Aktivisme Kelas Menengah Berbasis Media Sosial,” 149.
} 
diperoleh berdasarkan karakteristik yang dimiliki oleh masyarakat kota (urban population) yang lebih terbuka. Masyarakat kota juga lebih menyukai sesuatu yang bersifat simbolik, karenanya banyak simbol-simbol agama yang ditunjukkan oleh masyarakat kota dalam rangka memperlihatkan kesalehan pada khalayak. Adanya 212 Mart sebagai simbol minimarket hasil perjuangan umat Islam, menjanjikan hanya menjual barang halal, tidak menjual kondom, juga rokok serta ada waktu istirahat selama 15 menit saat tiba waktu shalat, berbelanja sambil berinfaq serta keterangan di dalam brosur bahwa ada persentase keuntungan hasil usaha (SHU) diperuntukkan bagi kaum dhu'afa yang besarannya tergantung pada kesepakatan yang dibuat pengurus. Untuk Koperasi Syariah Bauntung Batuah sebesar 5\% untuk yatim dan dhu'afa dan Koperasi Syariah Amanah Idaman dengan $7 \%$ untuk dana sosial. Hal tersebut merupakan simbol-simbol yang disukai, bersesuaian dengan karakter religius dalam bermuamalah yang dimiliki oleh orang Banua.

Seperti yang ditunjukkan Bapak MI (Ketua Koperasi Syariah Bauntung Batuah Banjarmasin) yang meski saat itu masih berada di tanah suci Mekkah, demi melihat dan mendengar pergerakan umat yang tergabung dalam komunitas Koperasi Syariah 212, kemudian memilih untuk juga terlibat dalam pembangunan usaha 212 Mart. Dari Mekkah kemudian ia mengkomunikasikan niat tersebut dengan beberapa koleganya di Banjarmasin. Niat ini disambut baik oleh sahabat-sahabat beliau yang juga memiliki niat dan spirit yang sama, ingin turut berpartisipasi memajukan ekonomi umat, khususnya wilayah Banjarmasin. Dari keterangan yang disampaikan Bapak S, banyak dari penggagas awal Koperasi Syariah Bauntung Batuah juga tergabung dan menjadi anggota di Koperasi Syariah 212. Penting diketahui bahwa syarat untuk mendirikan 212 Mart tidak bisa pribadi, hanya terdiri dari 1-2 orang saja, tapi basisnya harus komunitas, dan minimal 100 orang. Kemudian sejumlah 100 orang tersebut harus menjadi anggota dari Koperasi Syariah 212 dan mendaftar secara online di wmw.koperasisyariab212.co.id, demikian yang disampaikan oleh pengurus.

Masing-masing anggota komunitas di beberapa wilayah di Kalimantan Selatan ini berlombalomba menggalang minimal anggota sejumlah persyaratan tersebut. Seperti yang diungkapkan oleh salah satu pengurus Koperasi Syariah Amanah Idaman, 'padahal kami yang lebih dulu handak mendirikan 212 Mart nib di Banjarbaru, tapi tadahulu Banjarmasin wan Kotabaru'. Kendala mereka terdapat pada upaya mengumpulkan 100 orang anggota komunitas. Namun akhirnya dengan semangat 212 - demikian mereka menyebutnya-pada 24 Maret 2018, mereka memperoleh sertifikat pengukuhan sebagai komunitas Koperasi Syariah 212 dan berhak untuk mendirikan 212 Mart di Banjarbaru.

Berbeda dengan kasus Banjarmasin dan Kotabaru. Untuk Banjarmasin, Bapak MI dapat dengan cepat mengumpulkan anggota diwilayahnya. Bahkan disaat pendaftaran menjadi anggota mitra Koperasi Syariah 212, bapak ini berhasil mengumpulkan 250 orang anggota komunitas. Dengan posisi beliau sebagai salah satu pengusaha travel perjalanan wisata umrah dan haji juga sebagai salah satu wakil rakyat di DPRD Provinsi Kalimantan Selatan, ditengarai turut memberikan andil dalam memudahkan usaha tersebut. Begitu juga Kotabaru, peran dari Bapak MA sebagai pemilik travel haji dan umroh dapat dengan cepat mengumpulkan 100 orang anggota komunitas.

Pengumpulan sejumlah anggota agar tergabung dalam komunitas Koperasi Syariah 212, dengan spirit 212, kemudian menginvestasikan dana secara bersama-sama pula dalam mendirikan 212 Mart Amanah, Berjamaah dan Izzah, bertolak belakang dengan stereotype yang selama ini disematkan pada orang Banjar, individual-kompetitif. ${ }^{31}$ Streotype yang

\footnotetext{
31 Mochtar Buchori dan Wiladi Budiharga, “Tipe-Tipe Orientasi Sosial Budaya di Sembilan Daerah Penelitian di Indonesia “ Makalah dalam Seminar Orientasi Sosial Budaya III di Banjarmasin, diselenggarakan atas
} 
dirasakan lebih mendekati pada semangat ekonomi kapitalis. Namun, disisi lain orang Banjar juga dikenal memiliki konsep religiusitas yang tinggi. Mereka sangat hati-hati dalam persoalan yang menyangkut harta, terutama jual beli. Adanya akad yang harus dilafalkan secara zahir, kemudian adanya ucapan juallah seadanya, menunjukkan akan hal itu. Oleh karena itu kehadiran komunitas Koperasi Syariah 212 dengan spirit 212, berinvestasi dan berjuang bersama-sama (berjamaah) lalu mendirikan 212 Mart, menunjukkan adanya perubahan pola ekonomi orang Banjar. Peneliti melihat pola ini berubah karena pengaruh kesadaran ideologis yang kuat pasca Aksi 212 dan perubahan tersebut bisa dilakukan dengan efektif apabila dilakukan secara bersama-sama. Pada akhirnya ini dilakukan dengan membuat kebijakan bahwa Koperasi Syariah 212 dan mitranya, baru bisa didirikan dengan anggota minimal 100 orang.

Berbelanja sekaligus beramal, mungkin itu bahasa yang tepat untuk menggambarkan akan perilaku yang ditunjukkan oleh konsumen 212 Mart dan anggota koperasi. Karena disaat peneliti mendatangi lokasi, terdapat pernyataan konsumen dan anggota yang menyatakan akan hal tersebut. "Kami senang berbelanja di sini, karena ini milik orang Islam, sebagian dananya akan diberikan kepada orang Islam dan ini ditujukan untuk membantu ekonomi orang Islam". Kemudian pernyataan, ini kalo minimarket ampun orang Islam, sudah pasti dananya jua gasan orang Islam, demikian pernyataan yang disampaikan salah satu konsumen yang juga merangkap sebagai anggota di sana. Juga pernyataan dari salah satu anggota ke-4 dari Koperasi Syariah Bauntung Batuah Ibu MSH, bahwa bergabung di koperasi ini dan berbelanja di 212 Mart adalah sebuah keharusan bagi dirinya ketika ia berniat untuk hijrah. Hijrah ke ajaran Islam yang lebih sempurna dan perwujudan untuk itu adalah berekonomi secara syariah, berekonomi yang tidak hanya mencari keuntungan buat diri sendiri tapi juga keuntungan buat lingkungan sekitar, membantu kaum dhu'fa Muslim.

Beberapa pernyataan tersebut memang menunjukkan adanya rasa kecewa bahwa sebagian keuntungan bisnis retail modern seperti hypermart dan minimarket tertentu diberikan kepada kelompok agama lain, padahal umat Islam adalah pengguna terbanyak dari bisnis tersebut. Hal inilah yang kemudian banyak digunakan sebagai sarana untuk memengaruhi umat Islam lain untuk bergabung dan berbelanja di 212 Mart. Sebagaimana pernyataan dari sebuah grup whatsapp yang menuliskan bahwa ketika seseorang berbicara tentang kemiskinan, tentu bal ini tidak dapat dilepaskan dari realita kehidupan umat Islam saat ini. Namun disisi lain, umat Islam Indonesia banyak yang masib berbelanja di unit retail modern mencapai angka 300 triliun pertabun atau 8,2 triliun perbarinya dan 90\% pasar retail modern itu dikuasai oleb non muslim. Ditambah informasi bahwa 74\% tanah di Indonesia hanya dikuasai oleh 1\% saja dari penduduknya yang kaya raya. Artinya banyak kekayaan di Indonesia banya menumpuk disegelintir orang saja.

Meskipun sebenarnya 212 Mart—sebagai usaha dari koperasi—dapat dikategorikan sebagai minimarket retail modern, dan beberapa wilayah termasuk Banjarmasin dan Banjarbaru telah melakukan moratorium untuk mendirikan minimarket modern, tidak berlaku bagi 212 Mart. Pemerintah daerah dengan 'senang hati' mengizinkan pendirian 212 Mart. Di Banjarmasin, Walikota mempersilakan Koperasi Syariah Bauntung Batuah mendirikan 10

kerjasama LIPI dengan IAIN Antasari tanggal 28 Nopember - 1 Desember 1983, 43-44. Lihat juga Irfan Noor, "Demokrasi dan Budaya Banjar; Modal Kultur dan Penguatan Masyarakat Sipil", https://wmw.scribd.com/document/7851159/Demokrasi-Dan-Budaya-Banjar, diakses tanggal 23 April 2018, 3-4. Lihat juga Ahmadi Hasan, "Prospek Pengembangan Ekonomi Syariah di Masyarakat Banjar Kalimantan Selatan," AHKAM:Jurnal Ilmu Syariah 14, no. 2 (March 19, 2015). 
gerai 212 Mart di wilayahnya. ${ }^{32}$ Banjarbaru, Wakil Walikotanya bahkan mempersilahkan sebanyak-banyaknya 212 Mart berdiri di wilayahnya. Asalkan dilakukan dengan berjamaah, dimiliki oleh sebanyak mungkin anggota masyarakatnya serta di dalam minimarket memberikan tempat khusus untuk display barang home industry (UMKM).

\section{Perkembangan Mitra Koperasi 212 di Kalimantan Selatan}

Melihat animo yang cukup besar dari umat Islam di Kalimantan Selatan untuk bergabung dengan Koperasi 212 dan menjadi mitranya, maka menjadi penting untuk mengetahui sejauhmana perkembangan dari Mitra Koperasi 212 di Kalimantan Selatan. Beberapa temuan peneliti di lapangan dapat dijelaskan sebagai berikut:

Berdasarkan data online Kementerian Koperasi dan Usaha Kecil dan Menengah, Koperasi Syariah Bauntung Batuah beralamatkan di Jl. Pangeran Antasari No. 96A Banjarmasin Timur dengan Nomor Badan Hukum 006936/BH/M.KUKM.2/I/2018 yang dikeluarkan pada tanggal 12 Januari 2018. Adapun Nomor Induk Koperasi adalah 6371020040001. Dari awal berdiri pada 17 Jumadil Awwal 1439 H/3 Februari 2018 M hingga 24 Agustus 2019 sudah mempunyai 3 gerai untuk 212 Mart. Gerai pertama berada di Jl. Pangeran Antasari No. 96 A, gerai kedua berada di lingkungan RSUD dr. H. Moch. Anshari Saleh Banjarmasin Utara, dan gerai ketiga di lingkungan Masjid Al Muhajirin Kuin Utara. Sampai 24 Agustus 2019 sudah memiliki 599 orang anggota aktif dan RAT pertama sudah dilakukan pada bulan Juni 2019.

Sedangkan Koperasi Amanah Idaman Banjarbaru yang beralamat di Jalan Ahmad Yani Kilometer 34,5 Ruko 3 Dara Nomor 6A memiliki Nomor Badan Hukum Pendirian adalah 009422/BH/M.KUKM.2/VIII/2018 dan Nomor Induk Koperasi (NIK) 6372040120005. Koperasi ini baru akan membuka usaha 212 Mart-nya tanggal 1 September 2019, dengan anggota sudah mencapai angka 72 orang. Adapun untuk Koperasi Syariah Bumi Saijaan Berkah Kotabaru, sampai penelitian ini dilakukan tidak ditemukan data untuk Nomor Badan Hukum dan Nomor Induk Koperasi. Akan tetapi koperasi ini sudah memiliki satu gerai 212 Mart yang beralamatkan di Jl. Ahmad Yani KM. 296 Travel Al Multazam Group RT.03 RW. 01 desa Tegalrejo Kecamatan Kelumpang Hilir Kabupaten Kotabaru. Koperasi ini juga sudah memiliki 183 orang anggota dan direncanakan pada bulan Oktober 2019 akan mengadakan RAT untuk pertama kalinya. Sehingga jumlah keseluruhan anggota untuk tiga mitra Koperasi Syariah 212 di Kalimanta Selatan berada pada angka 854 orang anggota, dengan usia koperasi kurang dari 2 tahun.

Zald dan Ash (1966) menyatakan dalam teori mobilisasi sumber daya dibedakan berbagai tingkat dan tipe keterlibatan orang-orang dalam sebuah gerakan, dengan membedakan pengikut (sebagai anggota tetap atau sekedar peserta), konstituensi (sumber dari sumbersumber daya) dan para pencari keuntungaan (beneficiaries). Selanjutnya para individu dimobilisasi untuk mengambil bagian dalam aktivitas-aktivitas yang membentuk bagian dari strategis dan taktik sebuah organisasi gerakan. Namun anggota-anggota yang terhimpun di dalam sebuah gerakan bukanlah satu-satunya komponen yang dimobilisasi. Sebagaimana yang ditulis di atas, adanya uang, dukungan persenjataan, sumbangan dari para elit, dukungan media dan pembentukan opini publik yang cenderung mendukung gerakan

\footnotetext{
32 Sebagai catatan bahwa Walikota Banjarmasin (Ibnu Sina) berafiliasi dengan Partai Kesejahteraan Sejahtera (PKS), bahkan pernah menjadi Ketua Wilayah partai ini, yang memiliki kedekatan emosi dan ideologi dengan eksponen Aksi Massa 212, karena menjadi bagian yang tidak dapat dipisahkan dari kelompok gerakan ini.
} 
tersebut. ${ }^{33}$ Dalam hal ini, sejumlah anggota yang tergabung di dalam ketiga mitra Koperasi Syariah 212 tersebut, sebagian juga merupakan anggota aktif dari Koperasi Syariah 212. Di daerah, mereka kemudian menjadi anggota dari mitra Koperasi syariah 212. Adapun persyaratan untuk menjadi anggota pada masing-masing mitra Koperasi Syariah ini tidak jauh berbeda, yakni (1) muslim/muslimah; (2) foto berwarna ukuran 3x4 sebanyak 2 lembar; (3) mengisi formulir pendaftaram; (4) menyerahkan fotocopy ktp; (5) membayar simpanan pokok dan simpanan wajib, serta simpanan sukarela.

Hanya pada Koperasi Syariah Amanah Idaman Banjarbaru menggunakan istilah WNI (Warga Negara Indonesia). Bagi koperasi ini penggunaan istilah warga negara Indonesia, menurut peneliti dimaksudkan lebih kepada upaya menjaring sebanyak-banyaknya anggota yang dapat datang dari semua kalangan masyarakat dan tidak terlalu memedulikan terhadap keyakinan si anggota. Selain itu juga untuk menerapkan prinsip 'keterbukaan' dalam koperasi, yang mengandung makna bahwa keanggotaan koperasi bisa berasal dari mana saja, tanpa membedakan berasal dari suku, ras, agama, dan kelompok sosial. Hal ini nampak dari wawancara yang dilakukan dengan Ibu UL, bendahara koperasi yang menyatakan bahwa mereka berupaya mengajak sebanyak mungkin masyarakat untuk turut bergabung dengan koperasi mereka, tidak membedakan mereka dari status sosial apapun. Sehingga untuk koperasi ini, simpanan sukarela hanya ditujukan bagi anggota yang mau menginvestasikan dananya untuk dikelola dalam usaha 212 Mart. Sedangkan apabila anggota tidak berkenan, maka tidak ada pemaksaan untuk itu. Sama seperti perbankan syariah yang nasabahnya tidak terbatas dari umat Islam saja, karena perbankan syariah berupaya untuk mewujudkan apa yang disebut sebagai rahmatan lil 'alamin. Nampak disini fanatisme atas agama sudah mengalami pergeseran. Sesuai dengan teori liquid religion life pada masyarakat muslim menengah, bahwa mereka berupaya untuk lebih soft dalam melakukan kebijakan usaha mereka. Meskipun pada akhirnya ada dana dari sebagian SHU diberikan kepada kaum dhu'afa dan diutamakan adalah mereka yang beragama Islam juga.

Dalam upaya mempertahankan loyalitas keanggotaan, ada beberapa langkah yang dilakukan: Pertama, membentuk grup whatsapp dimana media tersebut diharapkan mampu menjalin komunikasi dan silaturrahmi antara pengurus dan para anggotanya. Di grup ini pun disampaikan segala bentuk perkembangan koperasi kepada semua anggota. Pertambahan jumlah anggota yang masuk serta keadaan neraca keuangan koperasi. Kedua, membuat laman di media facebook, dengan buka facebook home: Koperasi Syariah Bauntung Batuah, Kopsyah Amanahidamanbjb. Sedangkan untuk Koperasi Syariah Bumi Saijaan Berkah, peneliti tidak berhasil menemukannya di media facebook. Kedua cara ini merupakan cyberactivism, sarana efektif untuk menularkan dan memperkuat loyalitas anggota.

Ketiga, memberikan poin bagi anggota yang melakukan transaksi di masing-masing gerai 212 Mart dengan menyerahkan kartu keanggotaannya. Poin ini berguna untuk menambah jumlah SHU anggota tersebut pada akhir tahun. Akan tetapi kartu keanggotaan ini tidak berlaku bila anggota tersebut berbelanja di gerai 212 Mart mitra koperasi syariah lain. Jadi kartu anggota tersebut khusus untuk pemakaian transaksi yang dilakukan pada gerai 212 Mart milik koperasi syariahnya saja. Misalnya kartu anggota untuk komunitas Koperasi Syariah Bauntung Batuah Banjarmasin akan mendapatkan poin apabila ia berbelanja di tiga gerai 212 Mart Banjarmasin. Begitu juga untuk anggota komunitas Koperasi Syariah Amanah Idaman Banjarbaru. Berbeda dengan Koperasi Syariah Bumi Saijaan Berkah Kotabaru. Banyaknya transaksi yang dilakukan tidak mendapatkan poin dari koperasi. Hal

33 Joni Rusmanto, Gerakan Sosial: Sejarah Perkembangan Teori Antara Kekuatan Dan Kelemahannya, 1st ed. (Sidoarjo: Zifatama Publishing, 2012), 34-35. 
itu yang disampaikan oleh salah satu karyawan yang bekerja di sana. Nampaknya kartu anggota hanya berfungsi untuk menunjukkan identitas mereka, bahwa ia tergabung dalam komunitas Koperasi Syariah.

\section{Kendala yang Dihadapi Mitra Koperasi 212 di Kalimantan Selatan}

Setelah melakukan observasi dan wawancara di lapangan, ditemukan ada beberapa kendala yang dihadapi dalam perjalanan mitra Koperasi Syariah 212 di Kalimantan Selatan. Dari penuturan informan dapat dikelompokkan menjadi: pertama, tidak semua anggota dapat memahami karakter dari lembaga koperasi. Bahwa koperasi adalah merupakan usaha bersama dan milik bersama sehingga orientasi menjadi anggota koperasi tidak semata hanya untuk memperoleh keuntungan (profit), tetapi juga kebersamaan dalam membangun ekonomi umat dan membantu kaum dhu'afa. Sehingga penting semua anggota untuk berperan aktif dalam memajukan usaha mereka. Salah satu bentuk nyatanya adalah ajakan untuk sering berbelanja di 212 Mart, toko milik sendiri, belanja di awal bulan, dan belanja pada bulan Ramadhan. Bahkan untuk ini, para pengurus memiliki komitmen pribadi untuk tidak lagi berbelanja kebutuhan sehari-hari di toko retail modern lain, hanya berbelanja di 212 Mart milik mereka atau di pasar dan warung tradisional.

Kedua, ada beberapa anggota yang kemudian berhenti atau mengambil sebagian uang sumbangan sukarela mereka. Beberapa alasan yang dikemukakan antara lain adalah karena uang tersebut akan digunakan sebagai biaya untuk berobat dan keperluan ekonomi keluarga lainnya yang lebih urgen. Namun presentase dari hal ini sangatlah sedikit dan tidak berpengaruh pada perkembangan 212 Mart. Bagi anggota yang berhenti menjadi anggota, maka segala dana yang telah dititipkan dan seluruh SHU-nya yang belum diambil akan diberikan. Namun bagi anggota yang hanya mengambil atau mengurangi simpanan sukarelanya saja maka hal ini diperbolehkan dan ia masih termasuk dalam anggota koperasi tersebut.

Terakhir, manajemen produk dan harga di 212 Mart. Selama ini untuk memperoleh barangbarang yang akan dijual, pengelola 212 Mart khususnya kepala gudang harus kreatif dan berusaha keras mencari produsen dan supplier yang mampu menyediakan barang dengan harga yang murah. Agar harga yang ditetapkan di 212 Mart kompetitif dengan minimarket retail modern lain. Atau paling tidak harga yang diberikan tidak jauh berbeda dengan pasar atau warung tradisional sekitarnya. Oleh karenanya selama observasi dilakukan, pemberian diskon belanja bagi konsumen hampir tidak ada.

Meski demikian dari beberapa keterangan yang disampaikan, minat masyarakat daerah di Kalimantan Selatan sangat tinggi. Dari tanggapan yang disampaikan di media sosial, banyak yang mempertanyakan kapan nih daerah kita punya 212 Mart?. Sebagaimana yang disampaikan oleh Irfan Syauqi Beik, kekuatan Koperasi Syariah 212 terletak pada anggotanya. Kontribusi anggota sebagai belanja modal di 212 Mart sangat menentukan keberlangsungan dari koperasi. Setiap anggota harus memiliki kesadaran untuk itu. Oleh sebab itu beberapa strategi bisa dilakukan oleh 212 Mart: (1) harus mampu menumbuhkan komitmen untuk berbelanja di koperasinya sendiri, (2) memperkuat sistem distribusi barang, sehingga harga produk bisa bersaing, (3) kedepannya akan melakukan diversifikasi bisnis agar 212 Mart tidak hanya sekedar menjadi distributor/penyalur barang kepada konsumen tetapi juga menjadi produsen barang.

\section{Prospek Mitra Koperasi Syariah 212 di Kalimantan Selatan}

Melihat animo yang cukup kuat dari masyakat muslim di Kalimantan Selatan untuk bergabung dengan koperasi 212 menjadi tantangan tersendiri bagi para pengelola untuk 
lebih serius dalam membangun koperasi ini. Apalagi ini disertai jargon untuk membangun ekonomi umat yang tentunya diperlukan bukan semata semangat keberagamaan yang tinggi, tetapi juga profesionalitas dalam berusaha.

Meski permintaan untuk pendirian lembaga ini cukup tinggi, namun harus diakui bahwa keberadaan lembaga ini belumlah popular dan masih belum sampai ke akar rumput umat Islam, yang sebagian besarnya malah "asing" dengan koperasi ini. Oleh karena itu, keberadaan lembaga ini akan semakin prospek apabila dapat lebih membuka dirinya untuk juga dapat diminati oleh komunitas dengan latarbelakang ideologi yang berbeda. Lebihlebih secara politik gerakan 212 telah 'lemah' ketika calon yang didukungya yakni Prabowo kalah melawan Jokowi, yang notabene adalah presiden petahana.

Di luar persoalan politik, kesadaran bahwa persoalan ekonomi adalah kunci untuk membangun kesuksesan umat menjadi poin penting bagi gerakan Koperasi Syariah 212 untuk bisa lebih andi lagi dalam berbuat untuk kepentingan dan kemaslahatan bersama umat Islam. Hal penting yang bisa diamati dari gerakan koperasi 212 sebagai bagian dari kebangkitan ekonomi umat adalah adanya kebijakan pemerintah kota Banjarmasin dalam mendirikan 212 Mart yang mengharuskan setidaknya 20\% barang yang dijual merupakan produk UMKM merupakan bentuk dukungan atas ekonomi masyarakat mikro. Bahkan dari observasi yang dilakukan, peletakkan produk bome industry ini berada di sisi depan atau pojok depan 212 Mart. Terlihat dengan jelas adanya upaya lebih yang ditunjukkan untuk membantu pengenalan produk dan pemasaran produk UMKM. Ini tentunya poin tersendiri bagi pemerintah daerah yang memiliki keseriusan dalam pemberdayaan ekonomi umat Islam, yang menjadi masyarakat mayoritas di negeri ini.

Pada kasus 212 Mart Koperasi Syariah Bauntung Batuah sebagaimana penuturan dari salah satu anggota, mempersilakan kepada para anggotanya jika memiliki produk industri rumahan untuk memasarkan produknya di 212 Mart mereka. "Tapi syaratnya harus anggota dulu, hanyar kawa maandak barang di sana", demikian yang diungkapkan. Ini adalah salah satu strategi yang penting dalam pelibatan masyarakat untuk maju bersama-sama dalam hal menuju kesejahteraan.

Kemudian usaha bisnis retail ini merupakan usaha bersama yang dicetus umat Islam dengan prinsip Amanah, Berjamaah dan Izzah merupakan sarana terlahirnya peluang-peluang dalam meningkatkan ekonomi umat. Membuka lapangan pekerjaan, karena minimal satu 212 Mart mempekerjakan sekitar 4 orang lebih sebagai karyawan toko mereka. Kemudian memberikan peluang sarana investasi riil halal bagi umat Islam, yang tentu akan berimbas pada angka kemiskinan. Besarnya jumlah umat Islam di Indonesia, khususnya muslim kelompok menengah merupakan potensi bagi berkembangannya bisnis retail ini. Setidaknya keberadaan retail berjamaah ini memberikan alternatif tempat belanja halal bagi umat Islam.

\section{Penutup}

Sebagai catatan akhir dari penelitian ini dapat disimpulkan bahwa. Pertama, gerakan koperasi 212 telah memberikan warna tersendiri sebagai fenomena mutakhir dalam dinamika perkembangan ekonomi umat Islam. Bermula dari kesadaran melihat potensi umat yang besar, maka gerakan ini kemudian bisa diwujudkan. Fakta ini juga bisa disebut sebagai kebangkitan kelas menengah yang memiliki pemahaman dan kesadaran cukup tinggi dalam melihat persoalan ekonomi yang sedang dirasakan oleh umat Islam di Kalimantan Selatan, khususnya di kalangan moderns kota. Kedua, gerakan mitra Koperasi Syariah 212 terus mengalami perkembangan yang cukup pesat dengan semakin banyaknya gerai yang dibuka. 
Dukungan secara politis dari "penguasa" lokal memberi angin surga bagi perkembangan gerakan ini, di samping spirit keberagamaan yang dimiliki jamaahnya. Ketiga, gerakan mitra Koperasi Syariah 212 dalam praktik yang ditemukan di tiga wilayah penelitian, ternyata belum memiliki keseragaman dalam pengelolaannya. Ini tentunya menjadi tantangan tersendiri bagi pengelola untuk kesinambungan dan perkembangan dari gerakan ini. Pelibatan banyak orang dalam kepemilikan di samping memiliki kelebihan, juga pada saat yang sama bisa dipandang suatu kekurangan, karena akan banyak kesulitan dalam membuat suatu putusan penting. Keempat, mitra Koperasi Syariah 212 memiliki prospek yang cukup bagus mengingat pasar umat Islam sangatlah luas, khususnya untuk wilayah Kalimantan Selatan yang dikenal sebagai masyarakat yang relijius, termasuk dalam hal ekonomi. Oleh karena itu, pengelola koperasi harus lebih aktif untuk mengenalkan koperasi ini ke dalam lingkup masyarakat yang lebih luas lagi. Pembatasan ideologi yang kaku, bisa berdampak pada tidak tercapainya tujuan awal dari kehadiran kelompok ini untuk pembangunan dan pemberdayaan ekonomi umat.

\section{Daftar Pustaka}

Ali, Hasanuddin Ali, Hasanuddin. "Pasar Kelas Menengah Muslim yang Menggiurkan Kolumnis Tirto.ID.” tirto.id. Accessed August 8, 2019. https://tirto.id/pasar-kelasmenengah-muslim-yang-menggiurkan-cmw6.

Arianti, Anita. "Gerakan Pemurnian Islam Syekh Muhammad Arsyad Al-Banjari di Kalimantan Selatan.” AL-Fiker 14, no. 3 (2017): 377-390.

Bank syariab: dari teori ke praktek / Mubammad Syafii Antonio. Jakarta: Gema Insani Press, 2001.

"Dampak Pergerakan 212 Terhadap Perkembangan Ekonomi Umat Muslim." Koperasi Syariah 212 (blog), July 3, 2017. https://koperasisyariah212.co.id/dampakpergerakan-212-terhadap-perkembangan-ekonomi-umat-muslim/.

Damsar, and Indrayani. Pengantar Sosiologi Ekonomi. Jakarta: Prenada Media Group, 2015.

Groot, Kees de. "Three Types of Liquid Religion." Implicit Religion 11, no. 3 (February 26, 2009). https://doi.org/10.1558/imre.v11i3.277.

Hasan, Ahmadi. "Prospek Pengembangan Ekonomi Syariah Di Masyarakat Banjar Kalimantan Selatan.” AHKAM:Jurnal Ilmu Syariah 14, no. 2 (March 19, 2015). https://doi.org/10.15408/ajis.v14i2.1281.

Hasan, Noorhaidi. "Book Review: Islam Politik, Teori Gerakan Sosial, Dan Pencarian Model Pengkajian Islam Baru Lintas-Disiplin." Al-Jami'ab: Journal of Islamic Studies 44, no. 1 (2006): 241-250.

Jahar, Asep Saepuddin. "Transformasi Gerakan Ekonomi Islam Kontemporer." MIQOT: Jurnal Ilmu-Ilmu Keislaman 39, no. 2 (2015). .

Jati, Wasisto Raharjo. "Aktivisme Kelas Menengah Berbasis Media Sosial: Munculnya Relawan Dalam Pemilu 2014.” Jurnal Ilmu Sosial Dan Ilmu Politik 20, no. 2 (2016): 147-162.

"Kelas Menengah Sebagai Basis Pembangunan: Telaah Perspektif Webberian," n.d.

Jinan, Mutohharun. “Dilema Gerakan Pemurnian Islam.” Ishraqi IV, no. 1 (June 2008). 
Joni Rusmanto. Gerakan Sosial: Sejarah Perkembangan Teori Antara Kekuatan Dan Kelemahannya. 1st ed. Sidoarjo: Zifatama Publishing, 2012.

“Koperasi Syariah 212.” Koperasi Syariah 212 (blog). Accessed February 27, 2018. http://koperasisyariah212.co.id/koperasi-syariah-212/.

Muhammad Afdi Nizar. "Kelas Menengah (Middle Class) dan Implikasinya." ResearchGate. Accessed August 2019. https://www.researchgate.net/publication/279406954_Kelas_Menengah_Middle_ Class_dan_Implikasinya.

Nanang Martono. Sosiologi Perubahan Sosial: Perspektif Kalasik, Modern, Posmodern, Dan Poskolonial. 3rd ed. Jakarta: Rajawali Press, 2014.

Nashir, Haedar. "Purifikasi Islam Dalam Gerakan Padri di Minangkabau.” UNISLA 31, no. 69 (2008).

Damsar, Indrayani. Pengantar Sosiologi Ekonomi, Jakarta: Prenada Media Group, 2015.

Rahayu, Yayu Agustini. "Tingkatkan Ekonomi Rakyat, 212 Mart Gandeng UMKM Dan Warung Kecil." merdeka.com. Accessed April 24, 2018. https://www.merdeka.com/uang/tingkatkan-ekonomi-rakyat-212-mart-gandengumkm-dan-warung-kecil.html.

Rahmadi, Rahmadi. "Dinamika Intelektual Islam Di Kalimantan Selatan: Studi Genealogi, Referensi, Dan Produk Pemikiran." Jurnal Ilmu Ushuluddin 11, no. 1 (2016): 1-19. http://jurnal.iain-antasari.ac.id/index.php/ushuluddin/article/view/730.

Razi, Syafwan. "Dari Islam Radikal Ke Islam Pluralis Genealogi Gerakan Paderi Dan Pengaruhnya Terhadap Islam Pluralis Di Perbatasan Minangkabau." Masyarakat Indonesia 41, no. 1 (2016): 15-27.

Suriamijaya, Rahmad. "Pemikiran Dakwah Kaum Padri Di Sumatera Barat (Gerakan Dakwah Dalam Purifikasi Islam Di Masyarakat Minangkabau)." PhD Thesis, Universitas Muhammadiyah Surakarta, 2011.

Wahid, Ahmad Buyan. "Dakwah Salafi: Dari Teologi Puritan Sampai Anti Politik." Media Syariah 13, no. 2 (2017): 147-162.

Wahid, Din. "Nurturing Salafi Manhaj; A Study of Salafi Pesantrens in Contemporary Indonesia." Wacana 15, no. 2 (2014): 367-376.

"Walikota Resmikan 212Mart Banjarmasin.” Koperasi Syariah 212 (blog), February 5, 2018. http://koperasisyariah212.co.id/walikota-resmikan-212mart-banjarmasin/. 